This is the peer reviewed version of the following article: Bibak, B, Shakeri, F, Barreto, GE, Keshavarzi, Z, Sathyapalan, T,

Sahebkar, A. A review of the pharmacological and therapeutic effects of auraptene. BioFactors. 2019; 1- 13, which has been published in final form at https://doi.org/10.1002/biof.1550. This article may be used for non-commercial purposes in accordance With Wiley Terms and Conditions for self-archiving.

\title{
A review of the pharmacological and therapeutic effects of auraptene
}

2

3

4

5

\section{Abstract:}

There is a growing awareness in herbal medicine globally, as they are usually safe and devoid of significant adverse effects. Auraptene is a natural bioactive monoterpene coumarin ether and is consumed all over the world. There is growing evidence of the therapeutic benefits of auraptene. Auraptene, also known as aurapten and 7-geranyloxycoumarin, is a bioactive monoterpene coumarin from Rutaceae family, which is isolated from Citrus aurantium (Seville orange) and bael fruit (Aegle marmelos). Auraptene is a highly pleiotropic molecule which can modulate intracellular signaling pathways that control inflammation, cell growth and apoptosis. It potentially has a therapeutic role in the prevention and treatment of various diseases due to its antiinflammatory and antioxidant activities as well as its excellent safety profile. In the present article, various pharmacological and therapeutic effects of auraptene were reviewed. Different online databases using keywords such as auraptene, therapeutic effects and pharmacological effects were searched until the end of September 2018 for this purpose. Auraptene has been suggested to be effective in the treatment of a broad range of disorders including inflammatory disorders, dysentery, wounds, scars, keloids and pain. In addition, different studies have demonstrated that auraptene possesses numerous pharmacological properties including anti-inflammatory, antioxidative, anti-diabetic, anti-hypertensive and anti-cancer as well as neuroprotective effects. The present review provides a detailed survey of scientific researches regarding pharmacological properties and therapeutic effects of auraptene.

Keywords: Auraptene; pharmacological properties; chemopreventive. 


\section{Introduction:}

25 Herbal compounds are excellent candidates for finding new therapeutic options for the management of various diseases. Auraptene, also known as 7-geranyloxycoumarin, is a

27 prenyloxycoumarin found in plants belonging to Apiacea and Rutaceae families (1). Different

28 pharmacological and medicinal properties have been described for auraptene including antidiabetic (2), antiprotozoal (3), anti-genotoxic (4), anti-inflammatory (5) and immunomodulatory

(6) activities. Auraptene has been shown to have a significant effect on the prevention and treatment of various chronic diseases such as cystic fibrosis, nonalcoholic fatty liver and

32 hypertension (7).

Dietary administration of auraptene had cancer chemo-preventive effects in animal models of oral (8), breast (9), prostate (10), colon (11) and esophagus (12) cancers. The possible mechanism for these effects could be due to its glutathione S transferase inducing activity (13), lipid peroxidation (14), inhibition of key biological targets such as metalloproteinases (MMPs), glycoprotein P, peroxisome proliferator-activated receptors (PPARs), acetylcholinesterase (15) modulation of

38 inflammation (16), suppression of superoxide generation (17), inhibition of microglial activation and inflammatory mediators (18). This article aims to review the effects of auraptene in the

40 prevention and management of various conditions.

\subsection{Structural description, bioavailability, and safety of auraptene:}

42 Auraptene is a member of the class of coumarins that is umbelliferone in which the phenolic 43 hydrogen has been replaced by a geranyl group (Figure 1). It is isolated from several edible fruits 44 and vegetables and exhibits a variety of therapeutic properties. Auraptene can be prepared with a 45 reaction between 7-hydroxycoumarin and geranyl bromide in $\mathrm{K}_{2} \mathrm{CO}_{3}$ solution (19). Auraptene can 46 also be synthesized from umbelliferone by prenylation with $\mathrm{NaH}$ and geranyl bromide in 
47 dimethylformamide (DMF) (20). Auraptene can also be synthesized from 7-hydroxycoumarin

48 under alkaline conditions (DBU) using nuclear magnetic resonance (NMR) spectroscopic methods

49 including nuclear magnetic resonance spectroscopy (21).

50 When the acute and subacute toxicity of orally administrated auraptene in rats was investigated,

51 varying concentrations of auraptene (125, 250, 500, 1000 and $2000 \mathrm{mg} / \mathrm{kg}$ body weight) had no

52 effect on mortality for a period of two days. However, administration of auraptene for 28 days

53 showed some differences in the hematological and biochemical parameters of the treated and

54 untreated groups, but all differences were within normal reference ranges. Histopathological

55 investigation showed no toxic effects suggesting that suggested that auraptene is safe (22).

\section{2. Methods:}

57 We searched the literature available in ISI Web of Knowledge, Medline, Pub Med, Scopus and

58 Google Scholar databases for English articles published until September 2018. For this purpose, 59 we used appropriate keywords including auraptene, anticancer, anti-inflammatory, 60 cardioprotective, immunomodulation, anti-diabetic, and neuroprotective. Sixty-five studies were 61 considered eligible for inclusion in this review. Abstracts or unpublished articles and non-English 62 language articles were excluded.

\section{3. Results:}

64

65 3.1. Auraptene and cancer:

66 Cancer has high mortality and morbidity worldwide. There are a number of unwanted side effects 67 which occur during chemotherapy and radiotherapy. Natural therapies, including the use of plantderived compounds, potentially have a better safety profile (23). When the antiangiogenic activity 69 of auraptene was investigated in vitro, auraptene (0-500 nM) dose-dependently inhibited vascular 
70 endothelial growth factor (VEGF)-induced human umbilical vein endothelial cell (HUVEC) tube

71 formation, viability, migration and invasion of endothelial cells (24).

72 Effect of auraptene $(0-100 \mu \mathrm{M})$ in human gastric cancer cells (SNU-1 cell line) showed that 73 auraptene increased the sub-G1 phase cells and fragmented nuclei. It also induced depolarization 74 of the mitochondrial membrane and regulated apoptotic signaling by downregulating the 75 mammalian target of rapamycin (mTOR) pathway via Akt (protein kinase B) pathway (25).

76 The synergic effects of auraptene on anticancer drugs (cisplatin, paclitaxel, and 5-fluorouracil (577 FU)) were studied on esophageal carcinoma cells (KYSE30 cell line). Auraptene enhanced the 78 cytotoxicity of cisplatin, paclitaxel and 5-FU, as well as the apoptosis induced by anticancer 79 agents. Auraptene also down-regulated the expression of the cancer stem cell markers (12).

80 The effect of auraptene was investigated on the growth capacity of cervical cancer cells and 81 ovarian cancer cells. Results revealed that auraptene reduced cell viability and inhibited in vitro 82 migration and invasion, as well as suppressed matrix metalloproteinase (MMP)-2 and MMP-9 83 enzymatic activity (26). Combinatorial treatment with hyperthermia and auraptene in human colon 84 adenocarcinoma cells resulted in reduced cell viability and up-regulation of P21 expression 85 compared to untreated cells (11).

86 The effects of auraptene on beta-catenin-T-cell factor (TCF) activity as well as cell cycle 87 expression levels of beta-catenin target genes such as c-myc (a human gene over-expressed in 88 various cancers) were evaluated in human colorectal cancer cells. Treatment with auraptene for 89 48h inhibited cell growth with G2/M arrest in both caco-2 and DLD-1 cell lines. Auraptene 90 suppressed beta-catenin/TCF activity in caco-2 and enhanced its activity in DLD-1. The 91 modulation of beta-catenin/TCF activity by auraptene was inversely correlated with c-myc 
92 expression levels. This suggests that auraptene induced inhibition of growth in these cells by

93 different mechanisms independent on the modulation of beta-catenin-TCF signaling (27).

94 The effect of auraptene on the growth and sphere (surrogate tumors) formation of HT-29

95 (colorectal adenocarcinoma) wild type and FOLFOX (a combination chemotherapy regimen that

96 is used to treat colorectal cancer)-resistant and HT-116 (colorectal carcinoma) wild type and

97 FOLFOX-resistant were studied. Auraptene significantly inhibited the growth of parental and

98 FOLFOX-resistant lines in both types of cells. (28).

99 Antitumor activity of auraptene was studied against intraperitoneally transplanted azoxymethane 100 (AOM) in mice. Oral administration of (0.01 and $0.05 \%)$ of auraptene for 17 weeks significantly 101 reduced the incidences of colorectal adenocarcinomas, the multiplicity of colon adenocarcinomas 102 and colonic inflammation scores as well as increased the apoptotic index in colonic malignancies 103 (29). In another study, where the preventive effect of auraptene (250 ppm) in the diet for 10 weeks 104 on AOM induced colorectal preneoplastic lesions in mice was examined, auraptene significantly 105 reduced the number of aberrant crypt foci, ß-catenin-accumulated crypt, cell proliferation activity 106 but increased apoptotic cells (30). Similarly, administration of auraptene in the diet for 15 weeks 107 on colon carcinogenesis model induced by AOM/dextran sodium sulfate (DSS) in mice showed 108 auraptene suppressed the development of colonic adenocarcinomas. There was a reduction in 109 PCNA-labeling index and survivin-positive rate and increased terminal deoxynucleotidyl 110 transferase dUTP nick end labeling (TUNEL)-positive rate in colonic adenocarcinomas. 111 Additionally, auraptene reduced the incidence of colonic adenomas, total colonic tumors and 112 expression of pro-inflammatory cytokines. This suggests that auraptene inhibited colitis-related 113 colon carcinogenesis by modulating inflammation in mice (31). 
114 In another study the effect of auraptene (500 ppm) in the diet for 20 weeks on NMBA-induced 115 esophageal tumorigenesis in the rat was examined. Auraptene significantly reduced the incidence 116 and the frequency of tumors as well as the incidence of severe dysplasia. This might be mediated 117 by suppression of cell proliferation in the esophageal epithelium (32).

118 Auraptene has shown to significantly reduce extracellular signaling-regulated kinase (ERK) 1/2 119 activation, $H$. pylori adhesion and IL-8 production in human gastric carcinoma cell lines. In 120 addition, the knockdown of CD74 expression led to significant reduction of $H$. pylori adhesion but 121 elevated IL-8 production suggesting this effect is potentially mediated by disrupting ERK1/2 (33).

122 The effect of administration of auraptene in the diet for 7 weeks on liver carcinogenesis model 123 induced by $\mathrm{N}, \mathrm{N}$-diethylnitrosamine (DEN) in the rat was evaluated. Auraptene inhibited the 124 incidence of liver cell carcinoma and cell proliferation in liver cell neoplasms models (34). In a 125 similar study of auraptene on DEN-induced hepatocarcinogenesis cells showed auraptene 126 suppressed the occurrence of mutations in the beta-catenin gene in liver cell adenomas probably 127 by negative selection of mutation harboring neoplastic cells (35).

128 The effect of auraptene was investigated on the cell cycle and the genes related to the cell cycle in 129 mammary adenocarcinoma (MCF-7) cells line. Auraptene significantly reduced cyclin D1 protein 130 expression in these cell lines, inhibited IGF-1 stimulated S phase of cell cycle and modulated the 131 transcription of various genes involved in the cell cycle (9).

132 Tang et al. examined the in vivo effects of auraptene (500 ppm) in the diet for 15 weeks on prostate 133 carcinogenesis using transgenic rats with adenocarcinoma of the prostate. Auraptene significantly 134 reduced the epithelial component and high-grade lesions in the prostate. Furthermore, they 135 examined the chemotherapeutic effects of auraptene using human prostate cancer cells in vitro. 
136 Auraptene significantly reduced the cell viability in a dose-dependent manner and increased 137 apoptosis in these cell lines (10).

138 Effect of auraptene (100 and $500 \mathrm{ppm}$ ) in the diet for 38 weeks on AOM induced colon 139 carcinogenesis in the rat was examined. Dietary administration of auraptene significantly reduced 140 the incidence and multiplicity of colon adenocarcinoma and the production of aldehydic lipid 141 peroxidation products in the colonic mucosa. Auraptene suppressed the expression of cell 142 proliferation biomarkers in the colonic mucosa. It also increased the activities of phase II drug143 metabolizing enzymes in the liver and colon. The protective effects of auraptene in the AOM 144 model of colon carcinogenesis have been suggested to be related to its ability to suppress cell 145 proliferation and lipid peroxidation (14). Similarly, administration of auraptene in the diet after 146 induction of pulmonary metastasis in mice for 2 weeks reduced the numbers of metastatic lung 147 tumors, cross-sectional areas and volumes of the tumors and increased the apoptotic indices 148 compared to the controls (36).

149 The preventive effect of auraptene in the diet on $N$-methylnitrosourea (MNU)-induced mammary 150 carcinogenesis model in the rat showed auraptene inhibited cell proliferation and reduced the 151 expression of cyclin D1, c-Myc, and ODC in the tumors (37). The effect of auraptene was 152 investigated on cell proliferation in the human breast carcinoma cell line (MCF-7 and MDA-MB153 231). It showed auraptene significantly suppressed the proliferation in both the cell lines and 154 reduced insulin-like growth factor1 (IGF-1)-induced cyclin D1 expression in MCF-7 cells. In 155 addition, the in vivo effects of auraptene in the diet on MNU-induced mammary carcinogenesis in 156 the rat showed that auraptene delayed median time to the tumor, reduced incidence of tumor and 157 cyclin D1 expression (38). 
158 Dietary administration of auraptene after induction of oral carcinogenesis in the rat for 22 weeks 159 significantly reduced the frequency and incidences of tongue cancer, 5-bromodeoxyuridine 160 (BrdU)-labelling index and polyamine concentrations in the oral mucosa. It also increased the 161 activities of GST and QR in the tongue which suggests that the mechanism for this action might 162 be related to the suppression of cell proliferation (8).

163 Antitumor activity of auraptene was studied on the prostate cancer cells (PC3 and DU145 cell 164 line). After $24 \mathrm{~h}$, auraptene significantly exhibited a cytotoxic effect in a time-dependent manner 165 and increased the number of TUNEL-positive cells in a dose-dependent manner. Auraptene 166 activated caspase-9, caspase-3 and pro-apoptotic protein Bax. It also suppressed the expression of 167 anti-apoptotic proteins including Bcl-2 and myeloid cell leukemia 1 (Mcl-1) in these prostate 168 cancer cells. The possible mechanism of chemo-preventive effects of auraptene could be related 169 to Mcl-1-mediated activation of caspases (39).

170 The effect of auraptene was investigated on human renal cancer cells (RCC4 and RCC4/VHL cell 171 lines). Results indicated that auraptene inhibited glycolytic and mitochondrial metabolism as well 172 as VEGF and tube formation by HUVECs. It also decreased cell motility, induced hypoxia173 inducible factor $1 \alpha$ (HIF-1 $\alpha$ ) degradation in a von hippel-lindau (VHL)-independent manner and 174 promoted HIF-1a protein degradation by inhibition of translation initiation (40).

175 Topical administration of auraptene (16 nmol and $160 \mathrm{nmol} / \mathrm{o} .1 \mathrm{ml}$ in acetone) after induction of 176 skin tumor by 12-O-tetradecanoylphorbol-13-acetate (TPA) in the rat twice a week for 20 weeks 177 significantly reduced the incidence and number of tumors (17). Comparison of the cytotoxicity of 178 auraptene and umbelliprenin against some cancerous cell lines such as HeLa (cervical cancer cell 179 line), Jurkat (T cell leukemia cell line), MCF-7 (breast cancer cell line) and KYSE-30 (oesophageal 
carcinoma cell line) showed that auraptene is more cytotoxic than umbelliprenin (41). The anticancer effects of auraptene are summarized in Table 1.

\subsection{Auraptene and the nervous system:}

183 The effect of auraptene (6.0 mg/day, p.o.) on cognition was studied in healthy volunteers.

184 Cognitive assessments were evaluated using mild cognitive impairment (MCI) screen and mini185 mental state examination (MMSE) at baseline and at 24 weeks. Results showed that auraptene did not improve cognitive function after 24 weeks compared to baseline (42).

187 The effect of auraptene (10 and $25 \mathrm{mg} / \mathrm{kg} /$ day, s.c.) was evaluated 5 days before and 3 days after 188 the induction bilateral common carotid artery occlusion in mice. The results indicated that 189 auraptene decreased the numbers of ionized calcium binding adaptor molecule 1 positive cells, 190 glial fibrillary acidic protein positive cells and COX-2-positive cells. The presence of auraptene in 191 the brains of mice following (50 mg/kg, i.p.) administration of auraptene suggests that it has the 192 ability to pass through the blood-brain barrier. Results of in vitro study using cultured astrocytes 193 showed that auraptene suppressed the mRNA expression of the inflammatory cytokines (43). 194 Similarly, the effect of administration of auraptene on bilateral common carotid artery occlusion 195 induced cerebral global ischemia in mice showed that auraptene suppressed neuronal loss in the 196 hippocampal regions of CA1, CA2 and CA3, microglia activation by reduction IBA1-positive cells 197 in the hippocampus and COX-2 expression in astrocytes (16). Administration of auraptene intra198 peritoneally after induction of demyelination by cuprizone for 21 days increased the 199 immunoreactivity to oligodendrocyte transcription factor 2 (olig2) which is a marker of precursor 200 cells of oligodendrocytes and the number oligodendrocyte lineage precursor cells (OPCs). There 201 was also a reduction in microglial activation (44). 
202 The neuroprotective and memory enhancing effects of auraptene (4, 8 and $25 \mathrm{mg} / \mathrm{kg}$, p.o.) were 203 investigated in bilateral carotid artery occlusion model of cerebral global ischemia. The results 204 showed that auraptene significantly reduced the scape latency time and increased the percentage 205 of time spent and traveled pathway in the target quadrant in the Morris water maze. Auraptene also 206 reduced the MDA concentrations and increased glutathione (GSH) content in the cortex as well as

207 in the hippocampus. Histopathological data showed that auraptene protected cerebrocortical and 208 hippocampus neurons against ischemia (45). In the the rat pheochromocytoma cell line (PC12 209 cells), which is a model system for studies on neuronal proliferation and differentiation, auraptene 210 induced activation of the extracellular signal-regulated kinases (ERK)1/2. In addition, auraptene 211 promoted neural outgrowth from PC12 cells (46).

212 The effect of auraptene on the cognitive performance induced by scopolamine showed that 213 auraptene significantly reversed scopolamine-induced avoidance memory retention impairments,

21424 and $168 \mathrm{hr}$ after training trial in step-through task (47). The neuroprotective effects of auraptene 215 are summarized in Table 2.

\section{3.3. Auraptene and the cardiovascular system:}

217 The effect of auraptene (5 and $50 \mathrm{mg} / \mathrm{kg}$, orally) once daily for 6 weeks on myocardial infarction 218 (MI) in rats showed improved left ventricular fractional shortening (LVFS) and reduced posterior 219 wall thickness (PWT), myocardial cell diameter and perivascular fibrosis. In addition, auraptene 220 inhibited the activations of atrial natriuretic factor and MCP-1 mRNA levels (48).

221 When auraptene was administered intraperitoneally in normotensive and desoxycorticosterone 222 acetate (DOCA)-induced hypertensive rats, there was a significant reduction in mean systolic 223 blood pressure in both groups in a dose and time-dependent manner. This suggests that auraptene 
224 had anti-hypertensive properties and dietary supplementation with auraptene would be a

225 potentially beneficial strategy for the management of hypertension (49).

226 The influence of auraptene on mean arterial blood pressure and heart rate was studied in the rat.

227 Animals were divided to a control group that received single intravenous injections of normal

228 saline/DMSO, auraptene and nifedipine as a positive control. Although auraptene did not have

229 any significant effect on heart rate, it significantly reduced mean arterial blood pressure. This

230 suggests a potential antihypertensive effect of auraptene comparable to established anti-

231 hypertensives such as nifedipine at the used concentrations (50). Auraptene is also potent in vitro

232 inhibitor of the spontaneous beating of mouse myocardial cells. The $\mathrm{IC}_{50}$ of auraptene was 0.6

$233 \mu \mathrm{g} / \mathrm{ml}$, which is comparable to that of verapamil, a well-known $\mathrm{Ca}^{+2}$ antagonist (51). The

234 cardioprotective effects of auraptene are summarized in Table 3.

\section{3.5. Auraptene and the immune system:}

236 Auraptene significantly increased the expressions of IL-10, IFN- $\gamma$, IFN $\gamma /$ IL-4 and IL-10/IL-4 ratio

237 in non-phytohaemagglutinin (PHA)-stimulated lymphocytes. After PHA stimulation auraptene

238 significantly reduced the expressions of IL-4, IL-10, IFN- $\gamma$, NF- $\kappa$ B and NO and increased IFN-

$239 \gamma / \mathrm{IL}-4$ and IL-10/IL-4 ratio. This suggests the effects of auraptene on $\mathrm{T}$ cell subsets shifting

240 towards Th1 (IFN- $\gamma$ ) and Treg (IL-10) may play a therapeutic role in the management of Th2 cells

241 predominant conditions (52).

242 The effect of auraptene was evaluated on DNA damage in human peripheral lymphocytes induced

243 by $\mathrm{H}_{2} \mathrm{O}_{2}$. This demonstrated that auraptene significantly reduced the genotoxicity of $\mathrm{H}_{2} \mathrm{O}_{2}$. This is

244 most probably due to the prenyl moiety and suppression of superoxide anion $\left(\mathrm{O}^{2-}\right)$ generation (4). 
245 The effect of oral administration of auraptene on macrophage and lymphocyte functions in mice

246 showed that auraptene significantly increased glucose consumption of peritoneal macrophages,

247 activities of acid phosphatase and beta-glucuronidase as well as the production of IL-1 $\beta$ and TNF-

$248 \alpha(6)$. Studies on the effect of auraptene on T lymphocyte activation using mice CD3/CD28-

249 activated lymphocytes showed that auraptene inhibits the CD3/CD28-activated lymphocyte

250 proliferation by inhibition of cell cycle progression and cell division. Furthermore, auraptene

251 reduced the T cell cytokines (53). The immunomodulatory effects of auraptene are summarized in

252 Table 4.

\section{3.5. Auraptene and gastrointestinal system:}

254 The beneficial effect of auraptene on the lithocholic acid (LCA)-induced cholestatic liver injury 255 was investigated in mice. Different concentrations of auraptene were administered orally once a 256 day for 7 days to mice. Auraptene promoted bile acid efflux from the liver into the intestine via 257 induction of farnesoid X receptor (FXR) target genes canalicular bile salt export pump (Bsep) and 258 multidrug resistance-associated protein 2 (Mrp2) expression. It also promoted liver repair through

259 induction in the liver regeneration-related gene. It reduced hepatic uptake through inhibition in $260 \mathrm{Na}^{+} /$taurocholate cotransporting polypeptide (Ntcp) as well as suppressed the liver inflammation 261 through repressing inflammation-related genes. Auraptene reduced bile acid synthesis through 262 repressing FXR-target genes cholesterol 7a-hydroxylase (Cyp7a1) and oxysterol 12a-hydroxylase 263 (Cyp8b1) and increased bile acid metabolism through induction of sulfotransferase 2a1 (Sult2a1) 264 (54).

265 The effect of auraptene was investigated on azoxymethane (AOM)-induced colonic aberrant crypt 266 foci (ACF) in the male albino mice. Dietary administration of auraptene significantly reduced the 267 frequency of ACF in a dose-dependent manner and suppressed the expression of cell proliferation 
268 biomarkers and increased the activities of phase II enzymes (GST and QR) in the liver and colon.

269 This suggests that the protective effects of auraptene may be related to enhancement in phase II

270 enzymes activity in the liver and colon as well as suppression of cell proliferation in the colonic

271 mucosa (13).

272 The effect of auraptene in $H$. pylori-infected mice using a feeding needle showed that auraptene

273 inhibited H. pylori colonization and resultant gastric mucosal injuries, attenuated expressions of

274 CD74, IL-1 $\beta$, TNF- $\alpha$ in stomach tissue and level of macrophage inhibitory protein-2 (MIP-2) in

275 the serum (55). In vivo effects of auraptene in the diet on hepatic lipid metabolism using Otsuka

276 Long-Evans Tokushima fatty rats showed that auraptene reduced abdominal white adipose tissue

277 weight and hepatic triglyceride levels. It also increased the activities of carnitine

278 palmitoyltransferase and peroxisomal ß-oxidation and expression of acyl-CoA oxidase in a dose-

279 dependent manner in the liver (56).

280 Kawada et al., showed that auraptene acts as an agonist of the isoforms peroxisome proliferator281 activated receptors (PPAR) $\alpha$ and PPAR $\gamma$. At a concentration of $50 \mu \mathrm{M}$, auraptene activated PPAR $\alpha$ 282 and PPAR $\gamma$ while no effects were recorded for PPAR $\delta$. Furthermore, auraptene was also able to 283 enhance the mRNA expression level of adiponectin in 3T3-L1 adipocytes as well as the secretion 284 of adiponectin (57).

285 The effect of auraptene on thioacetamide (TAA)-induced hepatic fibrosis in mice showed a 286 reduction of liver collagen content. Auraptene also inhibited the activation of hepatic stellate cells 287 by down-regulating the expression of transforming growth factor-ß1 (TGF- $\beta 1$ ) and $\alpha$-smooth 288 muscle actin ( $\alpha$-SMA). There was also a reduction in the expression of NF- $\kappa B$, TNF- $\alpha$ and IL-1 $\beta$ 289 suggesting potential anti-inflammatory effects. However, the changes in these genes and protein 
290 expression, as well as ameliorative liver histology induced by auraptene were repealed by

291 farnesoid X receptor (FXR) antagonist guggulsterone (a phytosteroid found in the resin of the 292 guggul plant, Commiphora mukul) in vivo and FXR siRNA in vitro (58).

293 Auraptene when administered through the diet significantly reduced $H$. pylori colonization in $H$. 294 pylori-infected mongolian gerbil but did not have an effect on gastric inflammation (59). 295 Administration of auraptene (0.1\% w/w, in diet) after induction of ulcerative colitis by DSS model 296 in mice inhibited the gelatinolytic activity of MMP-7 as well as the expression of MMP-2 and 297 MMP-9 in the mucosa of the colon (60). The protective effects of auraptene on gastrointestinal 298 diseases are summarized in Table 5.

\section{3.6. Miscellaneous effects of auraptene:}

300 Auraptene (0.1 and 0.2\%, in diet) significantly reduced lipid accumulation in the liver and skeletal 301 muscle and increased the mRNA expression of the PPAR $\alpha$ target genes such as fatty acid 302 translocase (FAT)/CD36, acyl-CoA synthetase (ACS), acyl-CoA oxidase (ACO) and carnitine 303 palmitoyl transferase 1 (CPT1) involved in fatty acid oxidation in high-fat-diet (HFD)-fed KK-Ay 304 diabetic obese mice (2). The therapeutic potential of auraptene was studied in a mice model of 305 diabetes which was induced by streptozotocin. Results indicated that auraptene suppressed 306 astroglial activation and the hyperphosphorylation of tau at 231 of threonine in neurons. It also 307 recovered the suppression of neurogenesis in the dentate gyrus of the hippocampus in the 308 hyperglycemic mice. The potential protective effects of auraptene could be associated with its anti309 inflammatory and anti-oxidative action in the hyperglycemic brain (61).

310 Marquis and his colleagues evaluated the effect of auraptene on Porphyromonas gingivalis ( $P$. 311 gingivalis). It showed that auraptene inhibited the adherence of $P$. gingivalis to oral epithelial cells 
312 and reduced the secretion of cytokines and MMP by LPS-stimulated macrophages. It also inhibited

313 MMP-9 activity (62). The effects of auraptene on the secretion of inflammatory mediators and

314 chemokine by LPS-stimulated oral epithelial cells showed that auraptene reduced the secretion of

315 MMP-2, IL-6, IL-8 and chemokine (C-C motif) ligand (CCL)-5 secreted by Aggregatibacter

316 actinomycetemcomitans lipopolysaccharide-stimulated oral epithelial cells. Furthermore, the

317 effect of auraptene as a wound healing agent was examined using a gingival fibroblast model.

318 Auraptene improved wound closure by promoting cell migration (63).

319 The effect of auraptene on lipopolysaccharide (LPS)-stimulated murine macrophage line (RAW 320264.7 ) showed that auraptene had better biocompatibility and lower cytotoxicity compared to 321 aspirin. In addition, it significantly reduced the production of PGE2, levels of mRNA expression 322 and protein of COX-2 (5). Auraptene significantly suppressed the expression of monocyte 323 chemoattractant protein-1 (MCP-1), COX-2 and iNOS as well as TNF- $\alpha$ release from the RAW 324264.7 cell line $(64,65)$.

325 Auraptene inhibits $\mathrm{Ba}^{+2}$, acetylcholine or histamine-induced contractions of smooth muscles in 326 accordance with its spasmolytic activity. Studies of structure-activity relationship performed with 327 synthetic analogs of auraptene suggest that the observed spasmolytic activity is closely associated 328 with the presence of both the geranyl chain and the benzopyrone ring (66).

329 The effect of auraptene on the growth and viability of Leishmania major (L. major) Friedlin cells 330 showed auraptene (2, 5, 7, 10 and $15 \mu \mathrm{g} / \mathrm{ml})$ significantly inhibited growth of L. major 331 promastigotes at the used concentrations (3). The miscellaneous effects of auraptene are 332 summarized in Table 6. 


\section{Conclusions:}

There is growing evidence on the multiple health benefits of auraptene. Studies suggest that auraptene has potential therapeutic benefits in a wide range of conditions ranging from diabetes to cancer. These effects are mediated via a variety of mechanisms including anti-inflammatory, antioxidant and anti-tumor activities through its regulatory impacts on various molecular targets. This review showed a wide spectrum of effects of auraptene on different disorders both in experimental and clinical studies (Figure 2). With respect to the effects in cancer, auraptene has chemo-preventive and inhibitory effects on all stages of tumorigenesis, growth and proliferation of cancer cell lines. In experimental studies, auraptene had inhibitory effects on the proliferation of several cancer cell lines, the formation of DNA adducts, an increase of glutathione S-transferase activity and reduction of the number of aberrant crypt foci (precursors of colon cancers).

Auraptene showed improved effects on memory and behavioral deficits, motor incoordination and short-term memory as well as decreased cerebral infarct size. In cardiovascular system, auraptene treatment reduced high blood pressure, cardiac hypertrophy and vasodilation in experimental research. On the gastrointestinal system, auraptene reduced abdominal white adipose tissue weight as well as $\mathrm{H}$. pylori colonization and resultant gastric mucosal injuries. It also increased the activities of carnitine palmitoyltransferase, phase II enzymes and peroxisomal ß-oxidation as well as expression of Acyl-CoA oxidase in the liver and colon.

In experimental studies, auraptene caused a significant reduction on blood glucose levels and dietary glucose absorption, an increase of serum insulin levels and protection of pancreatic islets. In experimental models of periodontal disease, auraptene reduced the adherence of $P$. gingivalis to oral epithelial cells as well as the secretion of cytokines (IL-8 and TNF- $\alpha$ ) and MMP. Auraptene also has anti-inflammatory effects as well as reduction of immunological markers such as IL-4 and IL-10 and an increase of IFN- $\gamma$ in experimental studies. 
358 Auraptene due to its ability to affect a wide range of molecular targets with an excellent safety 359 profile could potentially be a potential candidate for the prevention and/or management of a 360 number of diseases. A wide range of pharmacological effects was reported for auraptene in the 361 published studies so far mainly in experimental studies. However, more clinical trials are needed 362 regarding the effects of auraptene before it could be translated in clinical practice.

365 Conflict of interest:

366 None.

367

368 
$369 \quad$ Figure Legend

370 Figure 1. Chemical structures of umbelliprenin (a) and auraptene (b).

371

372

373

374

375

376

377

378 Figure 2. Various effects of auraptene. (a)

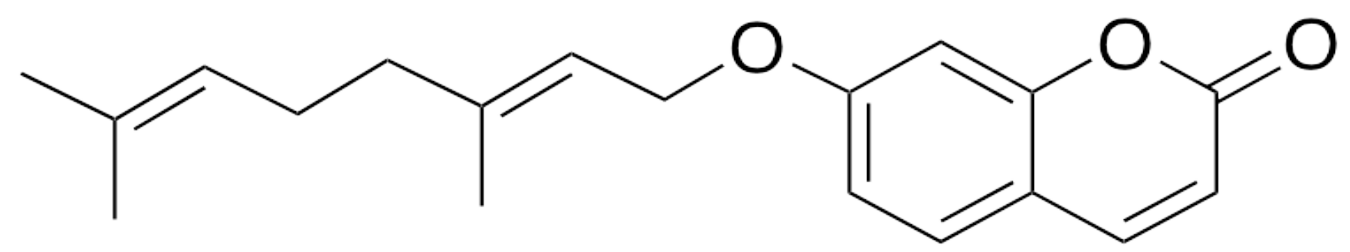

(b) 


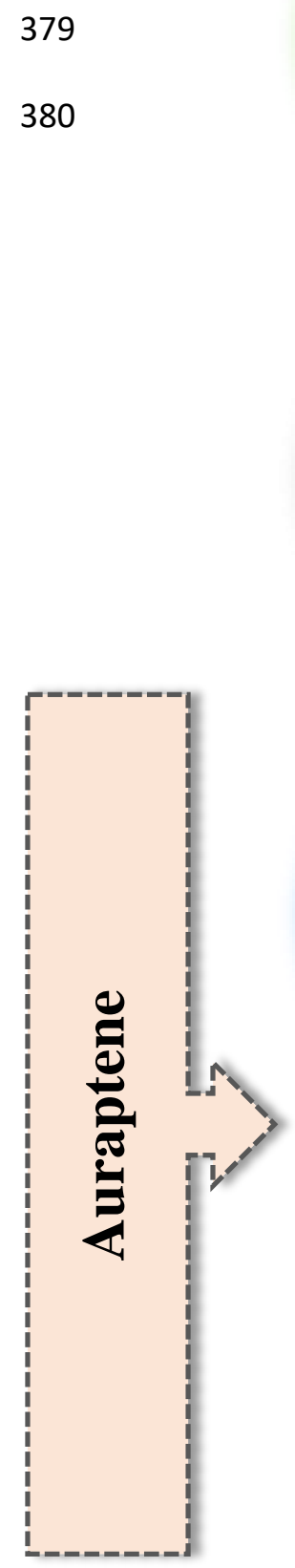

Anticancer effects

Inhibited tube formation, viability, migration and invasion of cells

Induced cell cycle arrest and apoptosis

Inhibited the growth and formation of colonospheres

Suppressed beta-catenin mutation

Inhibited cell proliferation

Inhibited glycolytic and mitochondrial metabolism

Suppressed neuronal loss and microglia activation

Reversed memory retention impairments

Reduced the scape latency time

Increased percentage time spent and traveled pathway in target quadrant

Improved left ventricular fractional shortening

Reduced posterior wall thickness myocardial cell diameter and perivascular fibrosis

Reduced mean systolic blood pressure and mean arterial blood pressure

Increased bile acid efflux into intestine from liver

Reduced hepatic uptake, liver inflammation, bile acid synthesis

Inhibited gastric mucosal injuries

Reduced H. pylori colonization in glandular stomach lesions

Increased glutathione S-transferase and quinone reductase activities

Reduced IL-4, IL-10, IFN- $\gamma$, NF- $\kappa B$

Increased IFN- $\gamma / \mathrm{IL}-4$ and IL-10/IL-4 ratio

Inhibited CD3/CD28-activated lymphocyte proliferation

Increased production of IL- $1 \beta$ and TNF- $\alpha$

Suppressed lipid accumulation

Inhibited enhancement in plasma glucose and insulin levels

Inhibited Porphyromonas gingivalis adherence to oral epithelial cells

Reduced PGE2 production

Suppressed the expression of MCP-1, COX-2

Inhibited growth of Leishmania major promastigotes 
381 Table 1. Summary of studies reporting anticancer effects of auraptene.

\begin{tabular}{|c|c|c|c|}
\hline Dose & Exp. model & Effect & Ref. \\
\hline $\begin{array}{l}0-500 \mathrm{nM}, \text { In } \\
\text { vitro }\end{array}$ & $\begin{array}{l}\text { VEGF-induced HUVEC } \text { growth } \\
\text { stimulation }\end{array}$ & $\begin{array}{l}\text { Inhibited tube formation, viability, migration } \\
\text { and invasion of HUVEC }\end{array}$ & (24) \\
\hline $\begin{array}{l}0-100 \mu \mathrm{M}, \\
\text { In vitro }\end{array}$ & Human gastric cancer cell line & $\begin{array}{l}\text { Induced cell cycle arrest and apoptosis in } \\
\text { SNU-1 cells via activation of p53 and } \\
\text { inhibition of mTOR signaling }\end{array}$ & $(25)$ \\
\hline $\begin{array}{l}\text { 5, } 10 \text {, and } 20 \\
\mathrm{ug} / \mathrm{ml}, \\
\text { vitro }\end{array}$ & Human esophageal carcinoma cell line & $\begin{array}{l}\text { Reduced the expression of CD44, BMI-1 } \\
\text { markers }\end{array}$ & $(12)$ \\
\hline $\begin{array}{l}6.25, \quad 12.5, \\
25,50, \text { and } \\
100 \mu \mathrm{M} \text {, In } \\
\text { vitro }\end{array}$ & $\begin{array}{l}\text { Human ovarian and cervical cancer cell } \\
\text { line }\end{array}$ & $\begin{array}{l}\text { Inhibited migration and invasion capacity of } \\
\text { human ovarian and cervical and ovarian } \\
\text { cancer by decreasing MMP-2, MMP-9 } \\
\text { activity }\end{array}$ & $(26)$ \\
\hline $\begin{array}{l}10 \text { and } 20 \\
\text { ug/ml, In } \\
\text { vitro }\end{array}$ & Human colon adenocarcinoma cell line & $\begin{array}{l}\text { Reduced cell viability } \\
\text { Up regulated of P21 expression }\end{array}$ & $(11)$ \\
\hline $\begin{array}{l}75 \mu \mathrm{M}, \quad \text { In } \\
\text { vitro }\end{array}$ & Human colorectal cancer cell line & Induced growth inhibition & $(27)$ \\
\hline $\begin{array}{l}2.5,5,10,20 \\
\text { and } 40 \mu \mathrm{M} \text {, } \\
\text { In vitro }\end{array}$ & $\begin{array}{l}\text { Human colorectal adenocarcinoma and } \\
\text { carcinoma cell lines }\end{array}$ & $\begin{array}{l}\text { Inhibited the growth and formation of } \\
\text { colonospheres }\end{array}$ & (28) \\
\hline $\begin{array}{l}0.01 \text { and } \\
0.05 \% \text {, p.o. }\end{array}$ & $\begin{array}{l}\text { AOM-induced colon carcinogenesis in } \\
\text { mice }\end{array}$ & $\begin{array}{l}\text { Inhibited the occurrence of colonic } \\
\text { adenocarcinoma }\end{array}$ & $(29)$ \\
\hline $\begin{array}{l}250 \quad \text { ppm, } \\
\text { p.o. }\end{array}$ & $\begin{array}{l}\text { AOM-induced colonic preneoplastic } \\
\text { lesions in mice }\end{array}$ & $\begin{array}{l}\text { Reduced the number of ACF, BCAC, cell } \\
\text { proliferation activity } \\
\text { Increased apoptotic cells }\end{array}$ & (30) \\
\hline $\begin{array}{l}100 \text { and } 500 \\
\text { ppm, p.o. }\end{array}$ & $\begin{array}{l}\text { AOM/ DSS induced colon } \\
\text { carcinogenesis in mice }\end{array}$ & $\begin{array}{l}\text { Suppressed the development of colonic } \\
\text { adenocarcinomas and colonic inflammation }\end{array}$ & (31) \\
\hline $\begin{array}{l}500 \quad \text { ppm, } \\
\text { p.o. }\end{array}$ & $\begin{array}{l}\text { NMBA-induced esophageal } \\
\text { tumorigenesis in rat }\end{array}$ & $\begin{array}{l}\text { Inhibited the development of esophageal } \\
\text { tumors }\end{array}$ & $(32)$ \\
\hline $\begin{array}{l}0-50 \mu \mathrm{M}, \text { In } \\
\text { vitro }\end{array}$ & Human gastric carcinoma cell lines & $\begin{array}{l}\text { Suppressed CD74 expression, H. pylori } \\
\text { adhesion and IL-8 production }\end{array}$ & (33) \\
\hline $\begin{array}{l}100 \text { and } 500 \\
\text { ppm, p.o. }\end{array}$ & $\begin{array}{l}\text { DEN-induced hepatocarcinogenesis in } \\
\text { rat }\end{array}$ & $\begin{array}{l}\text { Reduced the development of hepatocellular } \\
\text { carcinoma }\end{array}$ & (34) \\
\hline
\end{tabular}




\begin{tabular}{|c|c|c|c|}
\hline $\begin{array}{l}100 \text { and } 500 \\
\text { ppm, p.o. }\end{array}$ & $\begin{array}{l}\text { DEN-induced hepatocarcinogenesis in } \\
\text { rat }\end{array}$ & Suppressed beta-catenin mutation & (35) \\
\hline $\begin{array}{l}10 \mu \mathrm{M}, \quad \text { In } \\
\text { vitro }\end{array}$ & Human breast cancer cell line & $\begin{array}{l}\text { Reduced cyclin D1 protein expression } \\
\text { Inhibited IGF-1 stimulated S phase of cell } \\
\text { cycle } \\
\text { Modulated the transcription of many genes }\end{array}$ & (9) \\
\hline $\begin{array}{l}0,1 \times 10^{-5}, 5 \\
\times 10^{-5}, 1 \times \\
10^{-4}, 5 \times 10^{-} \\
4 \text { and } 1 \times 10^{-} \\
3 \mathrm{~mol} / \mathrm{L}\end{array}$ & Human prostate carcinoma cell lines & $\begin{array}{l}\text { Reduced cell viability } \\
\text { Increased apoptosis }\end{array}$ & (10) \\
\hline $\begin{array}{l}500 \quad \text { ppm, } \\
\text { p.o. }\end{array}$ & Prostate carcinogenesis using TRAP & $\begin{array}{l}\text { Reduced the epithelial component and high } \\
\text { grade lesions in the lateral prostate lobe }\end{array}$ & \\
\hline $\begin{array}{l}100 \text { and } 500 \\
\text { ppm, p.o. }\end{array}$ & $\begin{array}{l}\text { AOM-induced colon carcinogenesis in } \\
\text { rat }\end{array}$ & $\begin{array}{l}\text { Reduced the incidence and multiplicity of } \\
\text { colon adenocarcinoma, MDA and 4-HNE } \\
\text { Suppressed ODC and polyamine content } \\
\text { Increased GST and QR }\end{array}$ & (14) \\
\hline $\begin{array}{lr}250, & 500, \\
\text { and } & 1000 \\
\mathrm{mg} / \mathrm{kg}, & \text { p.o. }\end{array}$ & $\begin{array}{l}\text { Experimental metastasis mouse } \\
\text { model using B16BL6 melanoma cells }\end{array}$ & $\begin{array}{l}\text { Decreased the numbers of metastatic lung } \\
\text { tumors, cross-sectional areas and volumes of } \\
\text { the tumors } \\
\text { Increased apoptotic indices }\end{array}$ & (36) \\
\hline $\begin{array}{l}200 \text { and } 500 \\
\text { ppm, p.o. }\end{array}$ & $\begin{array}{l}\text { MNU induced mammary carcinogenesis } \\
\text { in rat }\end{array}$ & $\begin{array}{l}\text { Inhibited cell proliferation } \\
\text { Reduced the expression of cyclin D1, c-Myc, } \\
\text { and ODC }\end{array}$ & (37) \\
\hline $\begin{array}{l}1-50 \mu \mathrm{M}, \text { In } \\
\text { vitro }\end{array}$ & Human breast cancer cell line & $\begin{array}{l}\text { Suppressed proliferation } \\
\text { Reduced IGF-1-induced cyclin D1 } \\
\text { expression }\end{array}$ & (38) \\
\hline $\begin{array}{l}200 \text { and } 500 \\
\text { ppm, p.o. }\end{array}$ & $\begin{array}{l}\text { MNU induced mammary carcinogenesis } \\
\text { in rat }\end{array}$ & $\begin{array}{l}\text { Delayed median time to tumor } \\
\text { Reduced cyclin D1 expression and } \\
\text { incidence and multiplicity }\end{array}$ & \\
\hline $\begin{array}{l}100 \text { and } 500 \\
\text { ppm, p.o. }\end{array}$ & 4-NQO-induced oral carcinogenesis & $\begin{array}{l}\text { Reduced the frequency and incidences of } \\
\text { tongue carcinoma, BrdU-labelling index and } \\
\text { polyamine } \\
\text { Increased the activities of GST and QR }\end{array}$ & $(8)$ \\
\hline $\begin{array}{l}0,15,30, \\
60,90, \text { and } \\
120 \mu \mathrm{M}, \text { In } \\
\text { vitro }\end{array}$ & Human prostate cancer cell line & $\begin{array}{l}\text { Increased TUNEL-positive cells, sub-G1 } \\
\text { population } \\
\text { Cleaved poly (ADP-ribose) polymerase, } \\
\text { activated pro-apoptotic protein Bax, caspase- } \\
3 \text { and caspase-9 Suppressed the expression } \\
\text { of anti-apoptotic proteins }\end{array}$ & (39) \\
\hline
\end{tabular}




\begin{tabular}{|c|c|c|c|}
\hline $\begin{array}{l}0,25,50,75 \\
\text { and } 100 \mu \mathrm{M} \text {, } \\
\text { In vitro }\end{array}$ & Human renal cancer cell line & $\begin{array}{l}\text { Inhibited glycolytic and mitochondrial } \\
\text { metabolism, VEGF, and tube formation } \\
\text { HUVECs }\end{array}$ & $(40)$ \\
\hline $\begin{array}{l}16 \mathrm{nmol} \text { and } \\
160 \\
\text { nmol/o.1 ml } \\
\text { in acetone, } \\
\text { p.o. }\end{array}$ & TPA-induced skin tumor & $\begin{array}{l}\text { Reduced tumor incidence and the numbers of } \\
\text { tumors }\end{array}$ & $(17)$ \\
\hline $\begin{array}{l}10,20,40 \\
\mu \mathrm{g} / \mathrm{ml}, \mathrm{In} \\
\text { vitro }\end{array}$ & $\begin{array}{l}\text { Cervical cancer, breast cancer, } \\
\text { oesophageal carcinoma and T cell } \\
\text { leukaemia cell lines }\end{array}$ & Cytotoxic effect & (41) \\
\hline
\end{tabular}

Abbreviations: VEGF: vascular endothelial growth factor, HUVEC: human umbilical endothelial cells, AOM: azoxymethane, ACF: aberrant crypt foci, BCAC: ß-catenin-accumulated crypt, DSS: dextran sodium sulfate, NMBA: N-nitrosomethylbenzylamine, DEN: N,N-diethylnitrosamine, TRAP: transgenic rats developing adenocarcinoma of the prostate, MDA: malondialdehyde, 4-HNE: 4-hydroxy-2(E)-nonenal, ODC: ornithine decarboxylase activity, GST: glutathione S-transferase, QR: quinone reductase, MNU: $N$ methylnitrosourea, IGF-1: insulin like growth factor1, 4-NQO:4-nitroquinoline 1-oxide, BrdU: 5bromodeoxyuridine, VEGF: vascular endothelial growth factor, TPA: 12-O-tetradecanoylphorbol-13acetate, p.o.: oral administration,

Table 2. Summary of studies reporting neuroprotective effects of auraptene.

\begin{tabular}{|c|c|c|c|}
\hline Dose & Exp. model & Effect & Ref. \\
\hline $\begin{array}{l}10 \text { and } 25 \\
\mathrm{mg} / \mathrm{kg} / \text { day, } \\
\text { s.c. }\end{array}$ & $\begin{array}{l}2 \mathrm{VO} \text { induced cerebral global ischemia } \\
\text { in mice }\end{array}$ & $\begin{array}{l}\text { Reduced the numbers of IBA1-positive cells, } \\
\text { GFAP-positive cells } \\
\text { and COX-2-positive cells }\end{array}$ & (43) \\
\hline $\begin{array}{l}25 \text { and } 50 \\
\mathrm{mg} / \mathrm{kg} \text {, s.c. }\end{array}$ & $\begin{array}{l}\text { 2VO induced cerebral global ischemia } \\
\text { in mice }\end{array}$ & $\begin{array}{l}\text { Suppressed neuronal loss, microglia } \\
\text { activation, and COX-2 expression }\end{array}$ & (16) \\
\hline $\begin{array}{l}6.0 \mathrm{mg} / \text { day, } \\
\text { p.o. }\end{array}$ & Healthy volunteers & No effect on cognitive function & $(42)$ \\
\hline $\begin{array}{l}17 \text { and } 50 \\
\mathrm{mg} / \mathrm{kg}, \text { i.p. }\end{array}$ & $\begin{array}{l}\text { Cuprizone-induced demyelination in } \\
\text { mice }\end{array}$ & $\begin{array}{l}\text { Increased olig2 and the number OPCs } \\
\text { Reduced the microglial activation }\end{array}$ & (44) \\
\hline $\begin{array}{l}\text { 4, } 8 \text { and } 25 \\
\mathrm{mg} / \mathrm{kg}, \mathrm{p} .0 .\end{array}$ & $\begin{array}{l}2 \mathrm{VO} \text { induced cerebral global ischemia } \\
\text { in rat }\end{array}$ & $\begin{array}{l}\text { Reduced the scape latency time } \\
\text { Increased percentage time spent and traveled } \\
\text { pathway in target quadrant }\end{array}$ & $(45)$ \\
\hline $\begin{array}{l}10,30 \text { and } \\
50 \mu \mathrm{M}, \text { In } \\
\text { vitro }\end{array}$ & Rat pheochromocytoma cell line & $\begin{array}{l}\text { Induced the activation of ERK1/2 } \\
\text { Promoted neurite outgrowth }\end{array}$ & $(46)$ \\
\hline $\begin{array}{l}50,75 \text {, and } \\
100 \mathrm{mg} / \mathrm{kg} \text {, } \\
\text { s.c. }\end{array}$ & $\begin{array}{l}\text { Scopolamine-induced avoidance } \\
\text { memory retention impairments in mice }\end{array}$ & $\begin{array}{l}\text { Reversed memory retention impairments } \\
\text { induced by scopolamine }\end{array}$ & $(47)$ \\
\hline
\end{tabular}


Abbreviations: 2VO: 2-vessel occlusion, IBA1: ionized calcium binding adaptor molecule 1, GFAP: glial fibrillary acidic protein, olig2: oligodendrocyte transcription factor 2, OPCs: oligodendrocyte lineage

394 precursor cells, ERK: extracellular signal-regulated kinases,

395 Table 3. Summary of studies reporting cardioprotective effects of auraptene.

\begin{tabular}{|c|c|c|c|}
\hline Dose & Exp. model & Effect & Ref. \\
\hline $\begin{array}{l}5 \text { and } 50 \\
\mathrm{mg} / \mathrm{kg} \text {, p.o. }\end{array}$ & Myocardial infarction in rats & $\begin{array}{l}\text { Improved LVFS } \\
\text { Reduced PWT myocardial cell diameter and } \\
\text { perivascular fibrosis }\end{array}$ & (48) \\
\hline $\begin{array}{l}\text { 2, } 4,8 \text { and } 16 \\
\mathrm{mg} / \mathrm{kg} / \mathrm{day} \text {, } \\
\text { i.p. }\end{array}$ & DOCA-induced hypertensive in rats & Reduced MSBP & (49) \\
\hline $\begin{array}{l}125,250 \text { and } \\
500 \mathrm{mg} / \mathrm{kg} \text {, } \\
\text { i.v. }\end{array}$ & Normetensive rats & Reduced MABP & $(50)$ \\
\hline $\begin{array}{l}0.6 \mathrm{ug} / \mathrm{ml}, \text { In } \\
\text { vitro }\end{array}$ & Myocardial cells of rat & $\begin{array}{l}\text { Inhibited spontaneous beating of mouse } \\
\text { myocardial cells }\end{array}$ & (51) \\
\hline
\end{tabular}

Abbreviations: LVFS: left ventricular fractional shortening, PWT: posterior wall thickness, DOCA: desoxycorticosterone acetate, MSBP: mean systolic blood pressure, MABP: mean arterial pressure, p.o.: oral administration, i.p.: intraperitoneal, i.v.: intravenous,

Table 4. Summary of studies reporting immunomodulatory effects of auraptene.

\begin{tabular}{|c|c|c|c|}
\hline Dose & Exp. model & Effect & Ref. \\
\hline $\begin{array}{l}10,30 \text { and } \\
90 \mu \mathrm{M}, \text { In } \\
\text { vitro }\end{array}$ & PHA-stimulated human lymphocytes & $\begin{array}{l}\text { Reduced IL-4, IL-10, IFN- } \gamma, \mathrm{NF}-\kappa \mathrm{B} \text { and } \\
\text { NO } \\
\text { Increased IFN- } \gamma / \mathrm{IL}-4 \text { and IL-10/IL-4 ratio }\end{array}$ & $(52)$ \\
\hline $\begin{array}{l}50,100,200 \\
\text { and } 400 \\
\mathrm{mM}, \text { In vitro }\end{array}$ & $\begin{array}{l}\mathrm{H}_{2} \mathrm{O}_{2} \text {-induced DNA toxicity in human } \\
\text { lymphocytes }\end{array}$ & Reduced $\mathrm{H}_{2} \mathrm{O}_{2}$ genotoxicity & (4) \\
\hline $\begin{array}{l}100,200 \text { or } \\
400 \mathrm{mg} / \mathrm{kg} \text {, } \\
\text { p.o. }\end{array}$ & $\begin{array}{l}\text { Peritoneal macrophages and splenic } \\
\text { lymphocytes in mice }\end{array}$ & $\begin{array}{l}\text { Increased glucose consumption, activities of } \\
\text { acid phosphatase and beta-glucuronidase and } \\
\text { production of IL-1 } \beta \text { and TNF- } \alpha \\
\text { No effect on proliferation of spontaneous } \\
\text { splenic lymphocytes }\end{array}$ & (6) \\
\hline $\begin{array}{l}0,5,10,20 \\
\text { and } 40 \mu \mathrm{M} \text {, } \\
\text { In vitro }\end{array}$ & $\begin{array}{l}\text { CD3/CD28-activated lymphocytes } \\
\text { isolated from mice }\end{array}$ & $\begin{array}{l}\text { Inhibited CD3/CD28-activated lymphocyte } \\
\text { proliferation } \\
\text { Reduced IL-2, IFN- } \gamma \text { and IL-4 }\end{array}$ & (53) \\
\hline
\end{tabular}


Table 5. Summary of studies reporting protective effects of auraptene on gastrointestinal diseases.

\begin{tabular}{|c|c|c|c|}
\hline Dose & Exp. model & Effect & Ref. \\
\hline $\begin{array}{l}7.5,15 \text { and } \\
30 \mathrm{mg} / \mathrm{kg} \text {, } \\
\text { p.o. }\end{array}$ & LCA-induced cholestatic liver injury & $\begin{array}{l}\text { Increased bile acid efflux into intestine from } \\
\text { liver } \\
\text { Reduced hepatic uptake, liver inflammation, } \\
\text { bile acid synthesis } \\
\text { Increased bile acid metabolism }\end{array}$ & $(54)$ \\
\hline $\begin{array}{l}100 \text { and } 500 \\
\text { ppm, p.o. }\end{array}$ & AOM-induced colonic ACF in mice & $\begin{array}{l}\text { Reduced ACF frequency } \\
\text { Reduced expression of cell proliferation } \\
\text { indices } \\
\text { Increased GST and QR activities }\end{array}$ & (13) \\
\hline $\begin{array}{l}100 \text { and } 500 \\
\text { ppm, p.o. }\end{array}$ & H. pylori-infected mice & $\begin{array}{l}\text { Inhibited gastric mucousal injuries due to } H \text {. } \\
\text { pylori colonisation } \\
\text { Attenuated expressions of CD74, IL-1 } \beta \text {, } \\
\text { TNF- } \alpha \text {, and level MIP-2 }\end{array}$ & $(55)$ \\
\hline $\begin{array}{l}0.5 \text { and } 1 \\
\mathrm{~g} / \mathrm{kg} \text {, oral. }\end{array}$ & OLETF rats & $\begin{array}{l}\text { Reduced abdominal white adipose tissue } \\
\text { weight and TG } \\
\text { Increased carnitine acyl-CoA oxidase, } \\
\text { palmitoyltransferase and peroxisomal ß- } \\
\text { oxidation }\end{array}$ & $(56)$ \\
\hline $\begin{array}{l}1-100 \mu \mathrm{M}, \text { In } \\
\text { vitro }\end{array}$ & Human hepatocarcinoma cell line & $\begin{array}{l}\text { Increased PPAR } \alpha \text { and PPAR } \gamma \text { levels } \\
\text { Increased mRNA expression of adiponectin } \\
\text { in 3T3-L1 adipocytes and adiponectin } \\
\text { secretion }\end{array}$ & $(57)$ \\
\hline $\begin{array}{l}7.5,15 \text { and } \\
30 \mathrm{mg} / \mathrm{kg} \text {, } \\
\text { oral }\end{array}$ & TAA-induced hepatic fibrosis in mice & $\begin{array}{l}\text { Inhibited activation of HSCs } \\
\text { Reduced expression of TNF- } \alpha \text {, IL- } 1 \beta \text {, NF- } \\
\kappa \mathrm{B}\end{array}$ & (58) \\
\hline $\begin{array}{l}5,10 \text { and } 20 \\
\mu \mathrm{M}, \text { In vitro }\end{array}$ & Hepatocyte & Increased cell viability & \\
\hline $\begin{array}{l}100 \text { and } 500 \\
\text { ppm, p.o. }\end{array}$ & H. pylori-infected Mongolian gerbils & $\begin{array}{l}\text { Reduced } H \text {. pylori colonization in glandular } \\
\text { stomach lesions }\end{array}$ & (59) \\
\hline $\begin{array}{l}0.1 \% \mathrm{w} / \mathrm{w}, \\
\text { p.o. }\end{array}$ & DSS-induced ulcerative colitis in mice & $\begin{array}{l}\text { Suppressed gelatinolytic activity of MMP-7 } \\
\text { as well as MMP-2 and -9 expression }\end{array}$ & $(60)$ \\
\hline
\end{tabular}

Abbreviations: LCA: lithocholic acid, AOM: azoxymethane, ACF: aberrant crypt foci, MIP-2: macrophage 404 inhibitory protein-2, TG: hepatic triglyceride, OLETF: Otsuka Long-Evans Tokushima fatty, TAA: 405 thioacetamide, HSCs: hepatic stellate cells, DSS: dextran sulfate sodium, MMP: matrix metalloproteinase, 
408 Table 6. Summary of studies reporting miscellaneous effects of auraptene.

\begin{tabular}{|c|c|c|c|}
\hline Dose & Exp. model & Effect & Ref. \\
\hline $\begin{array}{l}0.1 \text { and } 0.2 \% \text {, } \\
\text { p.o. }\end{array}$ & HFD-fed KK-Ay obese diabetic mice & $\begin{array}{l}\text { Suppressed lipid accumulation } \\
\text { Inhibited enhancement in plasma glucose } \\
\text { and insulin levels } \\
\text { Increased mRNA expression of PPAR } \alpha \\
\text { target genes }\end{array}$ & (2) \\
\hline $\begin{array}{l}50 \mathrm{mg} / \mathrm{kg}, \\
\text { p.o. }\end{array}$ & STZ-induced diabetes in mice & $\begin{array}{l}\text { Suppressed astroglial activation and } \\
\text { neuronal hyper phosphorylation of tau at } 231 \\
\text { of threonine } \\
\text { Reversed suppression of neurogenesis in } \\
\text { hippocampal dentate gyrus }\end{array}$ & (61) \\
\hline $\begin{array}{l}0,12.5,25 \\
50 \text { and } 100 \\
\mu \mathrm{g} / \mathrm{ml}, \text { in } \\
\text { vitro }\end{array}$ & LPS-stimulated human macrophages & $\begin{array}{l}\text { Inhibits } P \text {. gingivalis adherence to oral } \\
\text { epithelial cells } \\
\text { Reduced TNF- } \alpha \text {, IL-8, MMP }\end{array}$ & $(62)$ \\
\hline $\begin{array}{l}0,0.2,1,5, \\
\text { and } 20 \mu \mathrm{M} \text {, } \\
\text { In vitro }\end{array}$ & $\begin{array}{l}\text { LPS-stimulated epithelial cells from } \\
\text { oral cavity }\end{array}$ & $\begin{array}{l}\text { Reduced secretion of chemokine (C-C motif) } \\
\text { ligand (CCL)-5, IL-6, IL-8, MMP-2 }\end{array}$ & (63) \\
\hline $\begin{array}{l}200,250, \\
300 \mu \mathrm{M}, \text { In } \\
\text { vitro }\end{array}$ & Murine macrophage cell line & $\begin{array}{l}\text { Reduced PGE2 production, mRNA } \\
\text { expression and COX-2 protein }\end{array}$ & (5) \\
\hline $\begin{array}{l}5,10 \text { and } 20 \\
\mu \mathrm{M} \text {, In vitro }\end{array}$ & Murine macrophage cell line & $\begin{array}{l}\text { Suppressed the expression of MCP-1, COX- } \\
2 \text {, iNOS and TNF- } \alpha\end{array}$ & $\begin{array}{l}(64, \\
65)\end{array}$ \\
\hline $\begin{array}{l}2,5,7,10 \\
\text { and } 15 \\
\mu \mathrm{g} / \mathrm{ml}, \text { In } \\
\text { vitro }\end{array}$ & Leishmania major cells & Inhibited growth of $L$. major promastigotes & (3) \\
\hline
\end{tabular}

409 Abbreviations: HFD: high-fat-diet, STZ: streptozotocin, P. gingivalis: Porphyromonas gingivalis, 410 MMP: matrix metalloproteinase, LPS: lipopolysaccharide, CCL-5: chemokine (C-C motif) ligand-

411 5, TNF- $\alpha$ : tumor necrosis factor, PGE2: prostaglandin E2, COX-2: cyclooxygenase-2, iNOS:

412 inducible nitric oxide synthase, MCP-1: monocyte chemoattractant protein-1, L. major: 413 Leishmania major, 


\section{References:}

418

419

420

421

422

423

424

425

426

427

428

429

430

431

432

433

434

435

436

437

438

439

440

441

442

443

444

445

446

447

448

449

450

451

452

453

454

455

456

457

458

459

460

461

462

463

[1] M. Curini, G. Cravotto, F. Epifano, G. Giannone (2006) Chemistry and biological activity of natural and synthetic prenyloxycoumarins. Current medicinal chemistry 13:199-222.

[2] N. Takahashi, M. Senda, S. Lin, T. Goto, M. Yano, T. Sasaki, S. Murakami, T. Kawada (2011) Auraptene regulates gene expression involved in lipid metabolism through PPAR $\alpha$ activation in diabetic obese mice. Molecular nutrition \& food research 55:1791-1797.

[3] H. Napolitano, M. Silva, J. Ellena, B. Rodrigues, A. Almeida, P. Vieira, G. Oliva, O. Thiemann (2004) Aurapten, a coumarin with growth inhibition against Leishmania major promastigotes. Brazilian journal of medical and biological research 37:1847-1852.

[4] F. Soltani, F. Mosaffa, M. Iranshahi, G. Karimi, M. Malekaneh, F. Haghighi, J. Behravan (2010) Auraptene from Ferula szowitsiana protects human peripheral lymphocytes against oxidative stress. Phytotherapy Research: An International Journal Devoted to Pharmacological and Toxicological Evaluation of Natural Product Derivatives 24:85-89.

[5] H. Yan, Z. Ma, X. Deng (2013) Anti-inflammatory effect of auraptene extracted from trifoliate orange (Poncirus trifoliate) on LPS-stimulated RAW 264.7 cells. Inflammation 36:1525-1532.

[6] T. Tanaka, H. Sugiura, R. Inaba, A. Nishikawa, A. Murakami, K. Koshimizu, H. Ohigashi (1999) Immunomodulatory action of citrus auraptene on macrophage functions and cytokine production of lymphocytes in female BALB/c mice. Carcinogenesis 20:1471-1476.

[7] G. Derosa, P. Maffioli, A. Sahebkar in: Drug Discovery from Mother Nature, (2016), Springer, pp 399407.

[8] T. Tanaka, K. Kawabata, M. Kakumoto, K. Matsunaga, H. Mori, A. Murakami, W. Kuki, Y. Takahashi, H. Yonei, K. Satoh (1998) Chemoprevention of 4-nitroquinoline 1-oxide-induced oral carcinogenesis by citrus auraptene in rats. Carcinogenesis 19:425-431.

[9] P. Krishnan, H. Kleiner-Hancock (2012) Effects of auraptene on IGF-1 stimulated cell cycle progression in the human breast cancer cell line, MCF-7. International journal of breast cancer 2012.

[10] M. Tang, K. Ogawa, M. Asamoto, N. Hokaiwado, A. Seeni, S. Suzuki, S. Takahashi, T. Tanaka, K. Ichikawa, T. Shirai (2007) Protective effects of citrus nobiletin and auraptene in transgenic rats developing adenocarcinoma of the prostate (TRAP) and human prostate carcinoma cells. Cancer science 98:471-477.

[11] M. Moussavi, F. Haddad, M. Matin, M. Iranshahi, F. Rassouli Improved efficacy of hyperthermia by auraptene in human colon adenocarcinoma cells.

[12] S. Saboor-Maleki, F. B. Rassouli, M. M. Matin, M. Iranshahi (2017) Auraptene attenuates malignant properties of esophageal stem-like cancer cells. Technology in cancer research \& treatment 16:519-527.

[13] T. Tanaka, K. Kawabata, M. Kakumoto, H. Makita, A. Hara, H. Mori, K. Satoh, A. Hara, A. Murakami, W. Kuki (1997) Citrus auraptene inhibits chemically induced colonic aberrant crypt foci in male F344 rats. Carcinogenesis 18:2155-2161.

[14] T. Tanaka, K. Kawabata, M. Kakumoto, A. Hara, A. Murakami, W. Kuki, Y. Takahashi, H. Yonei, M. Maeda, T. Ota (1998) Citrus auraptene exerts dose-dependent chemopreventive activity in rat large bowel tumorigenesis: the inhibition correlates with suppression of cell proliferation and lipid peroxidation and with induction of phase II drug-metabolizing enzymes. Cancer research 58:25502556.

[15] S. Genovese, F. Epifano (2011) Auraptene: a natural biologically active compound with multiple targets. Current drug targets 12:381-386.

[16] S. Okuyama, S. Minami, N. Shimada, N. Makihata, M. Nakajima, Y. Furukawa (2013) Anti-inflammatory and neuroprotective effects of auraptene, a citrus coumarin, following cerebral global ischemia in mice. European journal of pharmacology 699:118-123. 
[17] A. Murakami, W. Kuki, Y. Takahashi, H. Yonei, Y. Nakamura, Y. Ohto, H. Ohigashi, K. Koshimizu (1997) Auraptene, a Citrus Coumarin, Inhibits 12-0-Tetradecanoylphorbol-13-acetate-induced Tumor Promotion in ICR Mouse Skin, Possibly through Suppression of Superoxide Generation in Leukocytes. Japanese Journal of Cancer Research 88:443-452.

[18] S. Okuyama, T. Semba, N. Toyoda, F. Epifano, S. Genovese, S. Fiorito, V. A. Taddeo, A. Sawamoto, M. Nakajima, Y. Furukawa (2016) Auraptene and other prenyloxyphenylpropanoids suppress microglial activation and dopaminergic neuronal cell death in a lipopolysaccharide-induced model of Parkinson's disease. International journal of molecular sciences 17:1716.

[19] C. G. Angioni A, D’hallewin G, Pirsi FM, Reniero F, Schirra M. (1988) Synthesis and inhibitory activity of 7geranyloxycoumarin against Penicillium species in Citrus fruit.

. Phytochemistry 47:1521-1525.

[20] M. Curini, F. Epifano, F. Maltese, M. C. Marcotullio, A. Tubaro, G. Altinier, S. P. Gonzales, J. C. Rodriguez (2004) Synthesis and anti-inflammatory activity of natural and semisynthetic geranyloxycoumarins. Bioorganic \& medicinal chemistry letters 14:2241-2243.

[21] M. Askari, A. Sahebkar, M. Iranshahi (2009) Synthesis and purification of 7-prenyloxycoumarins and herniarin as bioactive natural coumarins. Iranian Journal of Basic Medical Sciences 12:63-69.

[22] T. Vakili, M. Iranshahi, H. Arab, B. Riahi, N. M. Roshan, G. Karimi (2017) Safety evaluation of auraptene in rats in acute and subacute toxicity studies. Regulatory Toxicology and Pharmacology 91:159164.

[23] A. G. Desai, G. N. Qazi, R. K. Ganju, M. El-Tamer, J. Singh, A. K. Saxena, Y. S. Bedi, S. C. Taneja, H. K. Bhat (2008) Medicinal plants and cancer chemoprevention. Current drug metabolism 9:581-591.

[24] T. Toliver, M. Chintalapati, J. N. Losso (2011) Anti-angiogenic activity of auraptene.

[25] J. Y. Moon, H. Kim, S. K. Cho (2015) Auraptene, a major compound of supercritical fluid extract of phalsak (Citrus Hassaku Hort ex Tanaka), induces apoptosis through the suppression of mTOR pathways in human gastric cancer SNU-1 cells. Evidence-Based Complementary and Alternative Medicine 2015.

[26] K. Jamialahmadi, S. Salari, N. S. Alamolhodaei, A. Avan, L. Gholami, G. Karimi (2018) Auraptene Inhibits Migration and Invasion of Cervical and Ovarian Cancer Cells by Repression of Matrix Metalloproteinasas 2 and 9 Activity. Journal of Pharmacopuncture 21:177.

[27] Y. Hirose, Z. Qiao, A. Murakami, H. Ohigashi, T. Tanaka, H. Mori, (2004), AACR.

[28] F. Epifano, S. Genovese, R. Miller, A. P. Majumdar (2013) Auraptene and its Effects on the Reemergence of Colon Cancer Stem Cells. Phytotherapy Research 27:784-786.

[29] H. Kohno, R. Suzuki, M. Curini, F. Epifano, F. Maltese, S. P. Gonzales, T. Tanaka (2006) Dietary administration with prenyloxycoumarins, auraptene and collinin, inhibits colitis-related colon carcinogenesis in mice. International journal of cancer 118:2936-2942.

[30] K. Hayashi, R. Suzuki, S. Miyamoto, Y. Shin-ichiroh, H. Kohno, S. Sugie, S. Takashima, T. Tanaka (2007) Citrus auraptene suppresses azoxymethane-induced colonic preneoplastic lesions in C57BL/KsJ$\mathrm{db} / \mathrm{db}$ mice. Nutrition and cancer 58:75-84.

[31] T. Tanaka, M. B. de Azevedo, N. Durán, J. B. Alderete, F. Epifano, S. Genovese, M. Tanaka, T. Tanaka, M. Curini (2010) Colorectal cancer chemoprevention by $2 \beta$-cyclodextrin inclusion compounds of auraptene and 4'-geranyloxyferulic acid. International journal of cancer 126:830-840.

[32] K. Kawabata, T. Tanaka, T. Yamamoto, A. Hara, A. Murakami, K. Koshimizu, H. Ohigashi, G. Stoner, H. Mori (2000) Suppression of $\mathrm{N}$-nitrosomethylbenzylamine-induced rat esophageal tumorigenesis by dietary feeding of auraptene. Journal of experimental \& clinical cancer research: CR 19:45-52.

[33] H. Sekiguchi, K. Irie, A. Murakami (2010) Suppression of CD74 expression and Helicobacter pylori adhesion by auraptene targeting serum starvation-activated ERK1/2 in NCI-N87 gastric carcinoma cells. Bioscience, biotechnology, and biochemistry 74:1018-1024. 
[34] K. Sakata, A. Hara, Y. Hirose, Y. Yamada, T. Kuno, M. Katayama, K. Yoshida, Q. Zheng, A. Murakami, H. Ohigashi (2004) Dietary supplementation of the citrus antioxidant auraptene inhibits $\mathrm{N}, \mathrm{N}$ diethylnitrosamine-induced rat hepatocarcinogenesis. Oncology 66:244-252.

[35] A. Hara, K. Sakata, Y. Yamada, T. Kuno, N. Kitaori, T. Oyama, Y. Hirose, A. Murakami, T. Tanaka, H. Mori (2005) Suppression of $\beta$-catenin mutation by dietary exposure of auraptene, a citrus antioxidant, in $\mathrm{N}, \mathrm{N}$-diethylnitrosamine-induced hepatocellular carcinomas in rats. Oncology reports 14:345-351.

[36] T. Tanaka, H. Kohno, M. Murakami, S. Kagami, K. El-Bayoumy (2000) Suppressing effects of dietary supplementation of the organoselenium 1,4-phenylenebis (methylene) selenocyanate and the Citrus antioxidant auraptene on lung metastasis of melanoma cells in mice. Cancer research 60:3713-3716.

[37] P. Krishnan, D. Windler, J. McLarty, K. Yan, B. Li, H. Kleiner, (2009), Federation of American Societies for Experimental Biology.

[38] P. Krishnan, K. J. Yan, D. Windler, J. Tubbs, R. Grand, B. D. Li, C. M. Aldaz, J. McLarty, H. E. KleinerHancock (2009) Citrus auraptene suppresses cyclin D1 and significantly delays N-methyl nitrosourea induced mammary carcinogenesis in female Sprague-Dawley rats. BMC cancer 9:259.

[39] J. C. Lee, E. A. Shin, B. Kim, B. I. Kim, M. Chitsazian-Yazdi, M. Iranshahi, S. H. Kim (2017) Auraptene induces apoptosis via myeloid cell leukemia 1-mediated activation of caspases in PC3 and DU145 prostate cancer cells. Phytotherapy Research 31:891-898.

[40] Y. Jang, J. Han, S. J. Kim, J. Kim, M. J. Lee, S. Jeong, M. J. Ryu, K.-S. Seo, S.-Y. Choi, M. Shong (2015) Suppression of mitochondrial respiration with auraptene inhibits the progression of renal cell carcinoma: involvement of HIF-1 $\alpha$ degradation. Oncotarget 6:38127.

[41] F. M. Motlagh, O. Gholami (2017) Comparison of Umbelliprenin and Auraptene in Cytotoxic Effects and Myeloid Cell Leukemia Type-1 (Mcl-1) Gene Expression. Indian Journal of Pharmaceutical Sciences 78:827-833.

[42] M. Igase, Y. Okada, M. Ochi, K. Igase, H. Ochi, S. Okuyama, Y. Furukawa, Y. Ohyagi (2018) Auraptene in the Peels of Citrus Kawachiensis (Kawachibankan) Contributes to the Preservation of Cognitive Function: A Randomized, Placebo-Controlled, Double-Blind Study in Healthy Volunteers. The journal of prevention of Alzheimer's disease 5:197-201.

[43] S. Okuyama, M. Morita, M. Kaji, Y. Amakura, M. Yoshimura, K. Shimamoto, Y. Ookido, M. Nakajima, Y. Furukawa (2015) Auraptene acts as an anti-inflammatory agent in the mouse brain. Molecules 20:20230-20239.

[44] M. Nakajima, R. Shimizu, K. Furuta, M. Sugino, T. Watanabe, R. Aoki, S. Okuyama, Y. Furukawa (2016) Auraptene induces oligodendrocyte lineage precursor cells in a cuprizone-induced animal model of demyelination. Brain research 1639:28-37.

[45] M. Ghanbarabadi, M. Iranshahi, S. Amoueian, S. Mehri, V. S. Motamedshariaty, S. A. Mohajeri (2016) Neuroprotective and memory enhancing effects of auraptene in a rat model of vascular dementia: Experimental study and histopathological evaluation. Neuroscience letters 623:13-21.

[46] Y. Furukawa, S. Watanabe, S. Okuyama, M. Nakajima (2012) Neurotrophic effect of citrus auraptene: neuritogenic activity in PC12 cells. International journal of molecular sciences 13:5338-5347.

[47] K. Tabrizian, N. S. Yaghoobi, M. Iranshahi, J. Shahraki, R. Rezaee, M. Hashemzaei (2015) Auraptene consolidates memory, reverses scopolamine-disrupted memory in passive avoidance task, and ameliorates retention deficits in mice. Iranian journal of basic medical sciences 18:1014.

[48] Y. Sunagawa, M. Funamoto, M. Fujita, K. Hasegawa, T. Morimoto (2014) Auraptene, a Coumaric Compounds Analogous, Activated Mitochondrial Function and Improved the Development of Heart Failure After Myocardial Infarction in Rats. Journal of Cardiac Failure 20:S144. 
[49] B. M. Razavi, E. Arasteh, M. Imenshahidi, M. Iranshahi (2015) Antihypertensive effect of auraptene, a monoterpene coumarin from the genus Citrus, upon chronic administration. Iranian journal of basic medical sciences 18:153.

[50] M. Imenshahidi, M. Eghbal, A. Sahebkar, M. Iranshahi (2013) Hypotensive activity of auraptene, a monoterpene coumarin from Citrus spp. Pharmaceutical biology 51:545-549.

[51] N. Kakiuchi, L. R. Senaratne, S.-L. Huang, X.-W. Yang, M. Hattori, U. Pilapitiya, T. Namba (1991) Effects of Constituents of Beli (Aegle marmelos) on Spontaneous Beating and Calcium-Paradox of Myocardial Cells1. Planta medica 57:43-46.

[52] V. R. Askari, V. B. Rahimi, S. A. Rezaee, M. H. Boskabady (2018) Auraptene regulates Th1/Th2/TReg balances, NF-KB nuclear localization and nitric oxide production in normal and Th2 provoked situations in human isolated lymphocytes. Phytomedicine 43:1-10.

[53] X. Niu, Z. Huang, L. Zhang, X. Ren, J. Wang (2015) Auraptene has the inhibitory property on murine T lymphocyte activation. European journal of pharmacology 750:8-13.

[54] X. Gao, T. Fu, C. Wang, C. Ning, Y. Kong, Z. Liu, H. Sun, X. Ma, K. Liu, Q. Meng (2017) Computational discovery and experimental verification of farnesoid $X$ receptor agonist auraptene to protect against cholestatic liver injury. Biochemical pharmacology 146:127-138.

[55] H. Sekiguchi, F. Takabayashi, K. Irie, A. Murakami (2012) Auraptene attenuates gastritis via reduction of Helicobacter pylori colonization and pro-inflammatory mediator production in C57BL/6 mice. Journal of medicinal food 15:658-663.

[56] K. Nagao, N. Yamano, B. Shirouchi, N. Inoue, S. Murakami, T. Sasaki, T. Yanagita (2010) Effects of citrus auraptene (7-geranyloxycoumarin) on hepatic lipid metabolism in vitro and in vivo. Journal of agricultural and food chemistry 58:9028-9032.

[57] K. Kuroyanagi, M.-S. Kang, T. Goto, S. Hirai, K. Ohyama, T. Kusudo, R. Yu, M. Yano, T. Sasaki, N. Takahashi (2008) Citrus auraptene acts as an agonist for PPARs and enhances adiponectin production and MCP-1 reduction in 3T3-L1 adipocytes. Biochemical and biophysical research communications 366:219-225.

[58] X. Gao, C. Wang, C. Ning, K. Liu, X. Wang, Z. Liu, H. Sun, X. Ma, P. Sun, Q. Meng (2018) Hepatoprotection of auraptene from peels of citrus fruits against thioacetamide-induced hepatic fibrosis in mice by activating farnesoid $X$ receptor. Food \& function 9:2684-2694.

[59] K. Takeda, H. Utsunomiya, S. Kakiuchi, Y. Okuno, K. Oda, K.-i. Inada, Y. Tsutsumi, T. Tanaka, K. Kakudo (2007) Citrus auraptene reduces Helicobacter pylori colonization of glandular stomach lesions in Mongolian gerbils. Journal of oleo science 56:253-260.

[60] K. Kawabata, A. Murakami, H. Ohigashi (2006) Auraptene decreases the activity of matrix metalloproteinases in dextran sulfate sodium-induced ulcerative colitis in ICR mice. Bioscience, biotechnology, and biochemistry 70:3062-3065.

[61] S. Okuyama, T. Nakashima, K. Nakamura, W. Shinoka, M. Kotani, A. Sawamoto, M. Nakajima, Y. Furukawa (2018) Inhibitory Effects of Auraptene and Naringin on Astroglial Activation, Tau Hyperphosphorylation, and Suppression of Neurogenesis in the Hippocampus of StreptozotocinInduced Hyperglycemic Mice. Antioxidants 7:109.

[62] A. Marquis, S. Genovese, F. Epifano, D. Grenier (2012) The plant coumarins auraptene and lacinartin as potential multifunctional therapeutic agents for treating periodontal disease. BMC complementary and alternative medicine 12:80.

[63] V. D. La, L. Zhao, F. Epifano, S. Genovese, D. Grenier (2013) Anti-inflammatory and wound healing potential of Citrus auraptene. Journal of medicinal food 16:961-964.

[64] A. Murakami, Y. Nakamura, T. Tanaka, K. Kawabata, D. Takahashi, K. Koshimizu, H. Ohigashi (2000) Suppression by citrus auraptene of phorbol ester-and endotoxin-induced inflammatory responses: role of attenuation of leukocyte activation. Carcinogenesis 21:1843-1850. 
604

605

606

607

608

609
[65] S. Lin, S. Hirai, T. Goto, T. Sakamoto, N. Takahashi, M. Yano, T. Sasaki, R. Yu, T. Kawada (2013) Auraptene suppresses inflammatory responses in activated RAW 264 macrophages by inhibiting p38 mitogen-activated protein kinase activation. Molecular nutrition \& food research 57:11351144.

[66] Y. Yamada, M. Okamoto, H. Kikuzaki, N. Nakatani (1997) Spasmolytic activity of aurapten analogs. Bioscience, biotechnology, and biochemistry 61:740-742.

610 